\title{
O założeniach i postulatach lingwistyki kulturowej (na przykładzie definicji PRACY)
}

\author{
Jerzy Bartmiński \\ prof. emeritus UMCS i IS PAN, członek czynny PAU \\ jerzy.bartminski@poczta.umcs.lublin.pl
}

\section{Streszczenie}

Artykut składa się z czterech części. W pierwszej autor przypomina początki formowania się lingwistyki kulturowej $w$ Polsce, zwiazane $z$ wrocławskim programem badań nad polska kultura narodowa, utworzeniem konwersatorium , Język a Kultura” (też serii wydawniczej pod takim tytułem) $i$ lubelskiego rocznika „Etnolingwistyka” $w$ roku 1988. W drugiej podaje przykłady traktowania faktów językowych $w$ perspektywie kulturowej, eksponując rolę stownictwa jako zwierciadła kultury. W trzeciej przedstawia 7-punktowe instrumentarium pojęciowe wypracowane $w$ ramach lubelskiej etnolingwistyki kognitywnej (językowy obraz s'wiata, stereotypy traktowane jako koncepty kulturowe, definicja kognitywna, punkt widzenia $i$ perspektywa interpretacyjna; profilowanie bazowych wyobrażeń; wartości; podmiot doświadczajacy, konceptualizujacy $i$ werbalizujacy). Na koniec na przykładzie jednego konceptu PRACA pokazane zostaja efekty analizy z zastosowaniem przedstawionego tego instrumentarium pojęciowego.

Stowa kluczowe: lingwistyka kulturowa, seria „Język a Kultura”, rocznik „Etnolingwistyka”, lubelska etnolingwistyka kognitywna, językowy obraz świata, koncept kulturowy, praca

Abstract

On the Assumptions and Claims of Cultural Linguistics. The Case of Polish PRACA 'work'

The study consists offour parts. The first part is devoted to the beginnings of cultural linguistics in Poland, connected with the Wroctaw-based programme for research on Polish national culture, the emergence of the "Language and Culture" research network (and a publication series with the same title), and the launch of the Lublin-based journal "Etnolingwistyka" in 1988. The second part contains examples of linguistic facts being viewed in cultural perspective, with a special role of the lexicon as the "mirror of culture". Part three presents a repertoire of seven conceptual constructs proposed in Lublin cognitive ethnolinguistics (linguistic worldview, stereotypes as cultural concepts, cognitive definition, viewpoint and interpretive perspective, profiling of base images, values, and the experiencing, conceptualizing, and speaking subject). Finally, the fourth part illustrates the application of this theoretical framework in an analysis of the Polish cultural concept of PRACA 'work'. 
Key words: cultural linguistics, "Language and Culture" series, journal Etnolingwistyka, Lublin cognitive ethnolinguistics, linguistic worldview, cultural concept, PRACA/work

\section{CZĘŚĆ I}

1. O początkach LK w Polsce pisał ostatnio Waldemar Czachur w książce Lingwistyka kulturowa i międzykulturowa (2017). Zarysowując kontekst powstania lingwistyki kulturowej w polskiej i niemieckiej przestrzeni kulturowej, warszawski germanista stwierdził, że:

„W Polsce rozwój myśli nad relacją języka i kultury, który przybiera również wymiar instytucjonalny, datować możemy na drugą połowę lat. 80., kiedy powstał periodyk „Etnolingwistyka” (od 1988) pod redakcją prof. Jerzego Bartmińskiego oraz, również od 1988, wrocławska seria „Język a Kultura”, jako wynik prac ogólnopolskiego konwersatorium pod tym samym tytułem".

(Czachur 2017: 12)

Jestem skłonny zgodzić się z tą opinią. A ponieważ miałem osobisty udział w obu tych dziś już zapomnianych działaniach, pozwólcie Państwo, że na początek zatrzymam się nad polskimi początkami LK i nieco uszczegółowię ten wątek ${ }^{1}$.

2. Początki LK wiążą się z Wrocławiem. Wprawdzie rocznik „Etnolingwistyka”, któremu W. Czachur wyznaczył tak znaczącą pozycję, jest wydawany w Lublinie, ale w istocie ma swoje początki we Wrocławiu, sięgające lat $70^{2}$. Stało się tak dlatego, że fundamentalny pomysł wiązania w badaniach naukowych języka z kulturą - a to stanowi rdzeń etnolingwistyki - narodził się w środowisku polonistycznym Uniwersytetu Wrocławskiego, kiedy dyrektorem tamtejszego IFP był niezapomniany prof. Czesław Hernas.

Uniwersytet Wrocławski w latach 70. otrzymał od władz w Warszawie zadanie zorganizowania prac nad tzw. problemem węzłowym „Polska kultura narodowa, jej tendencje rozwojowe i percepcja”. Kierujący tymi badaniami prof. Czesław Hernas prowadził otwarte seminarium, w którym uczestniczyli filolodzy (literaturoznawcy i lingwiści), folkloryści, kulturoznawcy, etnolodzy, m.in. trzech wybitnych Jerzych: Jerzy Cieślikowski, Jerzy Woronczak i Jerzy Jastrzębski, także Jan Miodek i Janusz Anusiewicz oraz zaczynający karierę naukową Piotr Kowalski, Jolanta Ługowska, a z badaczy przyjezdnych Roch Sulima z Warszawy i Włodzimierz Pawluczuk z Białegostoku (potem Krakowa). W istocie 
dyskutowano problemy antropologiczno-kulturowe. Profesor Hernas zaprosił mnie do udziału jako autora książki O języku folkloru (1973), powstałej z inspiracji Marii Renaty Mayenowej (a w istocie - Romana Jakobsona, zwolennika opisu dyferencjalnego, nastawionego na cechy specyficzne folkloru w relacji do potocznej gwary), i zaproponował podjęcie prac nad słownikiem języka folkloru. Zaproszenie przyjąłem z ochotą, zwłaszcza że propozycja ta została od razu wsparta finansowo i mogłem zatrudnić w Lublinie dwie młode osoby na pełne etaty z zadaniem przygotowani takiego słownika.

Zeszyt próbny tego słownika wyszedł w roku 1980 we Wrocławiu pt. Stownik ludowych stereotypów językowych, ze wstępem prof. Hernasa i moim. Z perspektywy lat można powiedzieć, że był to swego rodzaju „manifest etnolingwistyczny”, bo zamiast typowego słownika językowego powstał projekt słownika językowo-kulturowego. Recenzent zeszytu próbnego, Andrzej Maria Lewicki, napisał na łamach „Poradnika Językowego”, że ,jest to próba opracowania słownika nowego typu”, „niezwykle śmiały eksperyment leksykograficzny, nawet zbyt śmiały jak na aktualny poziom opracowania semantyki” (Lewicki 1984: 587-592).

3. Świadomi trudności, jakie przed projektem się piętrzą, zaczęliśmy organizować konferencje i wydawać tomy zbiorowe, poświęcone ważnym problemom teoretycznym. Od roku 1981 zaczęły się ukazywać kolejne tomy, wydawane przeważnie w ramach tzw. „czerwonej serii” lubelskiej:

- Bartmiński, Jerzy (red.) (1981) Pojęcie derywacji w lingwistyce,

- Lewicki, Andrzej, Maria (red.) (1982) Stałość i zmienność zwiazków frazeologicznych,

- Bartmiński, Jerzy (red.) (1988) Konotacja,

- Abramowicz, Maciej, Jerzy, Bartmiński (red.) (1989) Tekst ustny-texte oral: struktura i pragmatyka, problemy systematyki, ustność w literaturze.

- Bartmiński Jerzy (red.) (1990) Jezzkowy obraz świata,

- Bartmiński, Jerzy, Małgorzata, Mazurkiewicz-Brzozowska (red.) (1993) Nazwy wartości,

- Bartmiński, Jerzy (red.) (1993a) Pojęcie ojczyzny we wspótczesnych językach europejskich.

I inne.

Najważniejszymi teoretycznymi tekstami z tego okresu poszukiwań były zwłaszcza dwa artykuły: Definicja leksykograficzna a opis języka (Bartmiński 1984), w którym znalazł się 
postulat wyprowadzenia opisów semantycznych z wąskich ram strukturalnych i objęcia nimi cech określanych mianem konotacyjnych, kulturowych, kontekstowych, ,przyjęzykowych”3, oraz Definicja kognitywna jak narzędzie opisu konotacji (Bartmiński 1988), zawierająca projekt nowego typu definicji, która z czasem zdobyła szersze zastosowanie i znaczną popularność (o czym Bartmiński 2018, w druku).

4. W roku 1985 kierownictwo biura wrocławskiego (którym po aresztowaniu prof. Czesława Hernasa w roku 1982 kierował rektor Uniwersytetu Wrocławskiego, (prof. Mieczysław Klimowicz) powierzyło mi funkcję koordynatora II stopnia i odpowiedzialność za dział „Język w kulturze".

W dziale tym były już prowadzone prace:

- nad gramatyką komunikacyjną (Bogusława Dunaja),

- językiem telewizji (Zofii Kurzowej),

- nad kulturową funkcją języka (Janusza Anusiewicza),

- nad słownikiem języka folkloru (Jerzego Bartmińskiego).

Kiedy (na mój wniosek) biuro PW zgodziło się w roku 1985 powołać (i finansować)

Konwersatorium „Język a Kultura”, udało mi się pozyskać do badań z pogranicza języka i kultury nowe tematy i osoby:

- słownik języka Norwida (Jadwigi Puzyniny),

- funkcje języka (Renaty Grzegorczykowej),

- słownictwo międzyodmianowe (Andrzeja Markowskiego),

- etykietę językową (Małgorzaty Marcjanik),

- internacjonalizmy (Jolanty Maćkiewicz),

- semantykę leksykalną (Ryszarda Tokarskiego i Iwony NowakowskiejKempnej) $i$ in.

W szczytowym okresie wrocławskie biuro problemu węzłowego finansowało 17 zespołów badawczych.

5. Rok 1988 zapisał się podwójnie, bo w tym roku ukazał się w Lublinie pierwszy tom rocznika "Etnolingwistyka" i równolegle we Wrocławiu pierwszy tom wrocławskiej serii “Język a Kultura”. Od tego roku można mówić o „wymiarze instytucjonalnym” (jak to określił Czachur) refleksji nad relacją język-kultura.

W 1. tomie Etnolingwistyki w „Słowie wstępnym” znalazła się deklaracja programowa etnolingwistyki o następującej treści: 
„Etnolingwistyka jest tym kierunkiem współczesnego językoznawstwa, który za przedmiot swoich badań obiera język w jego złożonej relacji do kultury. A więc system językowy, jako zinstytucjonalizowany wytwór społeczny w całym bogactwie jego odmian, stylów, wariantów, a także w całej różnorodności jego użyć, w relacji do systemu kultury jako swoistego porządku ludzkich działań z wpisanymi w te działania wzorami i wartościami, a także do kultury jako wytworu owych działań”.

(Bartmiński 1988c: 5)

Za „główny przedmiot zainteresowan” etnolingwistyki redaktor rocznika uznał „pojęcie językowego obrazu świata, rozumianego jako obraz 'naiwny', leżący u podstaw języka, utrwalony w strukturze gramatycznej i znaczeniach słów, także w strukturze i znaczeniach tekstów".

(Bartmiński 1988c: 5)

Natomiast w pierwszym tomie wrocławskiej serii „Języka a Kultury” z roku 1988 - wydanym pod red. Anusiewicza i Bartmińskiego - znalazły się deklaracje na temat programu konwersatorium z siatką haseł do zaplanowanego językowego tomu Encyklopedii kultury polskiej (Bartmiński 1988) oraz programowa rozprawa Janusza Anusiewicza na temat kulturowej teorii języka. Anusiewicz pisał:

„Naszym zamierzeniem badawczym jest zajęcie się problematyką kulturowej teorii języka, rozumianej, najogólniej rzecz biorąc, jako teoria zajmująca się wieloaspektowością, wielopłaszczyznowością i wielofunkcyjnością języka w stosunku do kultury oraz penetrująca możliwie najpełniej pojęte relacje między językiem a kulturą, przy założeniu, że do treści, form, sposobów istnienia kultury, dochodzi się wychodząc od faktów językowych, a nie odwrotnie”.

(Anusiewicz 1988: 23)

6. Czy idea wiązania języka z kulturą była nowa? Nie. Wiązanie języka z kulturą ma w istocie długą tradycję historyczną, odpowiada duchowi europejskiej, zwłaszcza niemieckiej antropologii przełomu XVIII i XIX wieku, czasów Herdera i Humboldta. Ale we współczesnej nauce o języku, po okresie dominacji paradygmatu strukturalistycznego, autonomizującego język i badania nad językiem, idea traktowania języka w kontekście kultury przeżywa powtórne narodziny i ma tendencję wzrostową.

Potrzebę łączenia badań językowych z obrazem świata, wartościami, z kulturą i poznaniem, stale podkreślają glottodydaktycy, zajmujący się nauczaniem języków obcych (Zgółka 2006, Peeters 2015) i języka rodzimego jako obcego (w Polsce Zarzycka 2004, Miodunka i in. 2004, 
Ligara 2008, Gębal 2010, Dąbrowska 2017), wtórują im translatolodzy (por. Tabakowska 2004, Underhill 2012, Głaz 2015, Gicala 2017).

W obu ośrodkach - wrocławskim i lubelskim, inspirowano się dokonaniami etnolingwistów amerykańskich, Sapira i Whorfa, z tym, że autorzy wrocławscy (Anusiewicz zwłaszcza) obficie korzystali z opracowań niemieckich (Herdera, Humboldta, Triera, Weisgerbera), a lubelscy (Bartmiński, Niebrzegowska-Bartmińska) - z rosyjskich (Apresjana, Toporowa i Iwanowa, Tołstoja i Tołstojowej), oczywiście też i niemieckich (Herdera i Humboldta).

Jednak badania lubelskie wyrastały bardziej z rodzimej dialektologii i folklorystyki, korzystały z metodologii Bronisława Malinowskiego i zwłaszcza Anny Wierzbickiej, co zaowocowało ich względną oryginalnością (na co zwracali uwagę m.in. poznańska germanistka Marzena Guz (2012), krakowska anglistka Elżbieta Tabakowska (2013), lubelski anglista Adam Głaz (2015) i in. $\mathrm{i}$ in.

$\mathrm{Na}$ gruncie lingwistyki słowiańskiej postulat integralnego podejścia do języka i kultury najbardziej zdecydowanie wysunął w latach 60. twórca słowiańskiej etnolingwistyki, prof. Nikita Tołstoj, który jako inicjator i kierownik ,ekspedycji poleskiej” (nb. nawiązującej do przedwojennych badań nad Polesiem Kazimierza Moszyńskiego) doszedł do wniosku, że „nie jest możliwe 'czysto lingwistyczne' badanie leksyki dotyczącej kultury duchowej bez uwzględnienia wierzeń, obrzędów, reguł życia codziennego, mitologicznych wyobrażeń nosicieli języka". (Tołstoj 1992) ${ }^{4}$. Konsekwencją tego było stosowanie do opisów wspólnego instrumentarium terminologicznego opartego na takich pojęciach, jak system, opozycja i kontrast, paradygmatyka i syntagmatyka, tekst, model i wariant, wzorzec i jego realizacja itd.

Redaktor Etnolingwistyki podzielił te przekonania, pisząc w „Słowie wstępnym” do tomu 1. w roku 1988:

„Język i kultura są fenomenami par excellence ludzkimi. Są uniwersalne, semiotyczne, systemowe. Mają swój słownik, swoją gramatykę. Służą międzyludzkiej komunikacji. Równocześnie nie wyczerpują swojej istoty w prostej symbolizacji świata zewnętrznego, także ten świat modelują, współtworzą, projektują na miarę człowieka. Przekształcają przedmioty przynależne do świata rzeczy w przedmioty kultury przynależnego do świata człowieka, w przedmioty mentalne, o bogatych konotacjach"

(Etnolingwistyka 1,1988c: 6) 
Ponieważ akcent w badaniach lubelskich został położony na poznawczą stronę języka, lubelską etnolingwistykę z czasem przyjęto nazywać „kognitywną” (za: Zinken 2004, 2009, por. Nepop-Ajdaczyć 2007) dla odróżnienia od „etnolingwistyki etymologicznej” Władimira Toporowa i ,etnolingwistyki dialektologicznej” Nikity Tołstoja ${ }^{5}$.

7. Podsumowaniem pierwszego etapu prac konwersatorium „Język a Kultura” był tom Współczesny język polski wydany pod red. J. Bartmińskiego w roku 1993 we Wrocławiu jako tom II Encyklopedii kultury polskiej i wznowiony w rozszerzonej wersji w Lublinie w roku 2001. Tom miał w Lublinie pięć wydań.

Drugim podsumowaniem prac konwersatorium, dużej wagi teoretycznej, była książka Janusza Anusiewicza Lingwistyka kulturowa wydana w roku 1994 we Wrocławiu (dodruk w roku 1995). Wyprzedziła o rok książkę Gary Palmera Toward a Theory of Cultural Linguistics 1996, od której datuje się powstanie LK na Zachodzie.

Kwestią sporną była przez pewien czas nazwa nowo powstającej subdyscypliny lingwistyki: etnolingwistyka czy lingwistyka kulturowa. J. Anusiewicz w Lingwistyce kulturowej niesłusznie przeciwstawił je sobie, twierdząc (wbrew faktom), że etnolingwistyka ogranicza pole swoich zainteresowań do języka ludowego. W istocie od początku (od pierwszego tomu rocznika) etnolingwistyka obejmowała zarówno język ludowy, jak ogólnonarodowy. Błąd Anusiewicza skorygowała po latach Anna Dąbrowska (2004). Uznała, że oba terminy można używać zamiennie.

8. Wrocławski program „badań węzłowych” nad kulturą został zawieszony w momencie przewrotu politycznego 1989 i wprowadzenia nowego systemu grantowego. ${ }^{6}$ Konwersatorium „Język a Kultura” straciło mecenasa, jednak ostało się jako społeczne porozumienie międzyuczelniane. Spotkania odbywały się dalej, choć już na innych zasadach. W sumie w ramach konwersatorium w ciągu trzydziestu paru lat, od roku 1985 do 2017, odbyły się 44 konferencje $^{7}$, a ich owocem były liczne publikacje wydawane systematycznie w trzech seriach”: „białej” i „czerwonej” oraz w Etnolingwistyce. Do roku 2017 we wrocławskiej nieregularnie publikowanej „białej” serii Język a Kultura wydano 28 tomów; w Lublinie w (również nieregularnej) „czerwonej” serii pod różnymi tytułami - 35 tomów ${ }^{8}$, a regularnie wydawany rocznik „Etnolingwistyka” dobił w roku 2018 do 30 tomów (od tomu 28 ukazuje się także w wersji anglojęzycznej). W sumie - otrzymaliśmy 93 tomy, nie licząc osobno publikowanych monografii. 


\section{CZĘŚĆ II.}

9. U podstaw zarówno LK jak LEK leży teza, którą dobitnie sformułował Roman Jakobson, mówiąc - za antropologami - że ,język powinno się traktować jako integralną część życia społecznego", że ,język jest w istocie podstawą kultury” i ,język i kultura implikują się nawzajem" (Jakobson 1989: 472-473). W ramach LEK przyjmuje się, że język i kulturę łączy „paradoks wzajemnego uzależnienia” (Bartmiński 1993b; Łozowski (2014).

W myśl ideacyjnej koncepcji kultury jako systemu aksjonormatywnego na kulturę składa się ,wszystko to, co trzeba wiedzieć, czy też w co trzeba wierzyć, aby postępować w sposób zaakceptowany przez członków danej społeczności” (Ward Goodenough, za: Burszta 1986) a równocześnie - jak za Lakoffem przyjmuje Tomasz Krzeszowski - u podstaw języka naturalnego leżą wartości, i to one kształtują jego strukturę i funkcjonowanie (Krzeszowski 1994: 29$)^{9}$.

10. Udział „kultury w języku” - na różnych poziomach jego organizacji - stanowi dziś aksjomat LK. W tym momencie ograniczę się tylko do skrótowego wypunktowania problemu (zob. Bartmiński 2018b).

(a) Kulturowo uwarunkowane są wszystkie zachowania językowe; traktuje o tym ostatni 26. tom białej serii wrocławskiej z roku 2016.

(b) Podłoże kulturowe (intencjonalność, obraz świata, wartości) ma dyferencjacja stylów językowych (potocznego, artystycznego, naukowego, urzędowego (zob. np. Bartmiński 1993a: 19-21).

(c) Funkcjonowanie gatunków mowy (genry'ów), jak bajka, przysłowie, zagadka, przyśpiewka, zamówienie itd. opiera się na wzorcach, mających status społeczno-kulturowy (Niebrzegowska-Bartmińska 2007: 153-284).

(d) Zwroty adresatywne i formuły grzecznościowe są realizacją na materiale językowym konwencji społeczno-kulturowych (Marcjanik 1993: 271-281 i in.).

(e) Wzorce spójnościowe tekstu odwołują się do ogólnych zasad rządzących procesami myślowymi oraz do konwencji kulturowych (Bartmiński, Niebrzegowska-Bartmińska 2009).

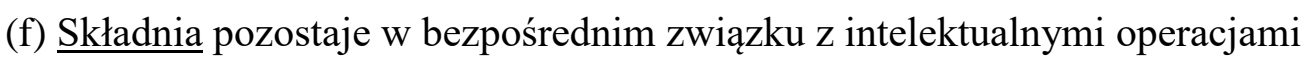
przeprowadzania rozumowań, co znajduje językowy wyraz m.in. w rozbudowanym systemie spójników.

(g) Frazeologia odzwierciedla dawne i współczesne wyobrażenia kulturowe; por. syzyfowa praca, wyglądać jak z krzyża zdjęty; rzucać komuś rękawice, nie zasypiać gruszek w popiele itp. 
(h) Techniki słowotwórcze wiążą się z przemianami społeczno-kulturowych modeli życia i sposobów konceptualizacji rzeczywistości. Przykładem jest ekspansja w polszczyźnie formacji żeńskich typu politolożka, znawczyni, ministra, wiążąca się z zabiegami o językową widoczność kobiet w życiu społecznym.

(i) Etymologia, która pyta o podstawy onomazjologiczne nazw, opisuje „formę wewnętrzną” słów; w nazwie pol. i ros. dom odnajdziemy kulturową ideę budowania mieszkania i tworzenia wspólnoty.

(j) Czytelne kulturowe podłoże mają też normy fleksyjne; podręcznikowym przykładem jest stosowanie w mianowniku liczby mnogiej końcówki -owie dla nazwania cieszących się szczególnym prestiżem osób męskich osobowych: panowie, profesorowie, senatorowie).

(k) Kulturowo motywowane są także zjawiska z poziomu fonetyki i prozodii, kiedy np. mówi się o stylach wymowy, o recytacji, deklamacji, rapowaniu, itp.

(1) Najważniejszą dziedziną języka, w której związki języka i kultury przyjmują formę najbardziej wyrazistą jest słownictwo. Jest ono „bardzo czułym wskaźnikiem kultury” - jak za Edwardem Sapirem powtarza Anna Wierzbicka (2007: 71). Dla podkreślenia ścisłego związku leksyki z kulturą glottodydaktycy operują pojęciem leksykultury (np. Bronisława Ligara 2008 za Robertem Glissonem). W ramach LEK przyjmuje się, że definicje (kognitywne) są tekstami kultury, są definicjami kulturowymi.

\section{CZEŞŚĆ III.}

Z tym stwierdzeniem przechodzę do trzeciej części mojego referatu, w której zaprezentuję instrumentarium LEK służące definiowaniu konceptów aksjologicznych, jako tekstów kultury.

11. LEK operuje zestawem siedmiu kluczowych pojęć, które są narzędziami stosowanymi w pracach analitycznych:

(1) językowy obraz świata,

(2) stereotyp,

(3) definicja kognitywna,

(4) punkt widzenia i perspektywa interpretacyjna,

(5) profilowanie i profil,

(6) wartości,

(7) podmiot. 
Każdemu z tych pojęć w swoim czasie poświęcono osobną konferencję, por. publikacje:

(ad 1) Bartmiński, Jerzy (red.) (1990) Językowy obraz świata ${ }^{10}$.

(ad 2) Anusiewicz, Janusz, Jerzy, Bartmiński (red.) (1998) Stereotyp jako przedmiot lingwistyki ${ }^{11}$.

(ad 3) Bartmiński, Jerzy (red.) (1988) Konotacja; Bartmiński, Jerzy, Ryszard, Tokarski (red.) (1993) O definicjach i definiowaniu ${ }^{12}$.

(ad 4) Bartmiński Jerzy, Stanisława, Niebrzegowska-Bartmińska, Ryszard, Nycz (red.) (2004) Punkt widzenia w języku i w kulturze; Bartmiński, Jerzy, Stanisława, NiebrzegowskaBartmińska, Ryszard, Nycz (red.) (2004) Punkt widzenia w tekście i w dyskursie.

(ad 5) Bartmiński, Jerzy, Ryszard, Tokarski (red.) (1993) Profilowanie w języku i w tekście ${ }^{13}$.

(ad 6) Bartmiński, Jerzy, Małgorzata, Mazurkiewicz-Brzozowska (red.) (1993) Nazwy wartości; Bartmiński, Jerzy (2004) Język w kręgu wartości ${ }^{14}$.

(ad 7) Bartmiński, Jerzy Anna, Pajdzińska (red.) Podmiot w języku i kulturze (2008).

Kolejne problemy LK podejmowane omawiane były w innych tomach zarówno „czerwonej serii” lubelskiej ${ }^{15}$, jak „,białej” wrocławskiej, której pierwsze dwa tomy (jak wspomniałem) ukazały się w wersji powielaczowej w roku 1988 i w roku 1989, poza cenzurą, po czym w roku 1991 zostały wznowione z dodaniem podtytułów ${ }^{16}$.

Dokonam krótkiej prezentacji wymienionych 7 kluczowych pojęć LEK.

\subsection{Językowy obraz świata (JOS) jest}

„,zawartą w języku, różnie zwerbalizowaną interpretacją rzeczywistości, dającą się ująć w postaci zespołu sądów o świecie. Mogą to być sądy „utrwalone”, czyli mające oparcie w samej materii języka, a więc w gramatyce, słownictwie, w kliszowanych tekstach (np. w przysłowiach), ale także sądy presuponowane, $\mathrm{tj}$. implikowane przez formy językowe, utrwalone na poziomie społecznej wiedzy, przekonań, mitów i rytuałów".

(Bartmiński 2006a: 12)

W realnej komunikacji bazowe wyobrażenia funkcjonują jako podmiotowe wizje (Bartmiński 1990, Niebrzegowska-Bartmińska 2015: 41). Pojęcie JOS nawiązuje do trójkąta semiotycznego; każdy z trzech składników terminu odpowiada jednemu wierzchołkowi trójkąta: 


\section{językowy + obraz + świata \\ znak + koncept + desygnat}
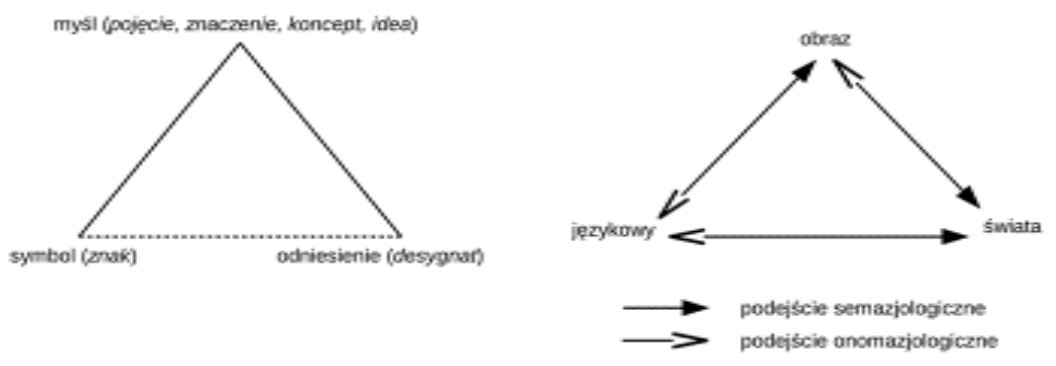

Rycina 1. Pojęcie JOS.

Podejścia semazjologiczne (od nazwy do znaczenia) i onomazjologiczne (od świata do nazwy) są komplementarne wobec siebie, niesprzeczne. Możemy równie dobrze pytać o znaczenie (,konotację” w szerokim, Millowskim sensie słowa) wyrazów słońce, księżyc, gwiazdy, jak o sposoby nazywania 'największego dziennego światła na niebie', 'największego nocnego światła na niebie', 'małych świateł na niebie widocznych nocą' itp. Dobrą prezentację problemu JOS w lingwistyce niemieckiej, amerykańskiej i polskiej przynosi książka Marzeny Guz (2012).

12.2. Składnikami JOS są stereotypy czyli koncepty kulturowe ${ }^{17}$. Ostatnio ograniczamy użycie terminu stereotyp na rzecz konceptu ze względu na powszechne (niedające się przezwyciężyć) używanie stereotypu w sensie uprzedzeń, więc z negatywną konotacją. Termin koncept - z dodatkiem: kulturowy nie sprawia takich problemów. Jest definiowany najkrócej mówiąc, - jako 'pojęcie nacechowane aksjologicznie i wyposażone w swoiste konotacje' (Gryshkova 2014). ${ }^{18}$ Na koncept składa się więc szerszy zespół cech niż na pojęcie. Pojęcie zawiera tylko cechy poznawcze: matka to 'kobieta, która urodziła', teściowa to 'matka męża'; natomiast stereotyp/ koncept zawiera także treści emotywne i pragmatyczne, tj. bogatą konotację językową i kulturową: matka 'kochająca', 'opiekuńcza', 'troskliwa' itd., teściowa 'nieżyczliwa', 'złośliwa'.

12.3. Narzędziem opisu konceptów jest definicja kognitywna, która za cel główny ma zdanie sprawy ze ,sposobu pojmowania przedmiotu przez mówiących danym językiem, tj. z utrwalonej społecznie i dającej się poznać poprzez język i użycie języka wiedzy o świecie, kategoryzacji jego zjawisk, ich charakterystyki i wartościowania.” (Bartmiński 1988: 69-170). 
Definicja kognitywna jest tekstem kultury w rozumieniu szkoły tartuskiej i zarazem tekstem narracyjnym, swoistą narracją o przedmiocie (Bartmiński 2013, 2014b, 2018c). Dyskusyjna jest kwestia „otwartego” charakteru definicji kognitywnej (Bartmiński, Tokarski 1993), bo otwartość, która jest cechą samego znaczenia, a nie cechą samej definicji, „która otwarty zespół cech zawsze sprowadza do zapisu w większym lub mniejszym stopniu ograniczonego" (Niebrzegowska-Bartmińska 2017: 566), cech, dla których można wskazać „dowody językowe" (Wierzbicka 1993; podobnie Bartmiński 2015).

\subsection{Punkt widzenia to}

„czynnik podmiotowo kulturowy, decydujący o sposobie mówienia o przedmiocie, w tym m.in. o kategoryzacji przedmiotu, o wyborze podstawy onomazjologicznej przy tworzeniu jego nazwy, o wyborze cech, które są o przedmiocie orzekane w konkretnych wypowiedziach i utrwalone w znaczeniu".

(Bartmiński 1990/2006: 105)

12.5. Profilowanie jest subiektywną (mającą swój podmiot) operację językowo-pojęciową, polegającą na swoistym ukształtowaniu obrazu przedmiotu poprzez ujęcie go w określonych aspektach podkategoriach, fasetach), takich jak pochodzenie, cechy, wygląd, funkcje, zdarzenia, przeżycia itp., w ramach pewnego typu wiedzy i zgodnie z wymogami określonego punktu widzenia (Bartmiński, Niebrzegowska 1998, Bartmiński 2018a, 2018b).

12.6. Wartości - jak już była o tym mowa - stanowią rdzeń każdej kultury i zarazem są nieodłączne od języka. Są czynnikiem, który steruje tworzeniem bazowych wyobrażeń i ich profilowaniem w dyskursie (Zob. tomy: JKW 2004, JWP 2006, WJOSS 1-4.).

12.7. Podmiot - jest instancją, która rządzi dyskursem, werbalizacją i konceptualizacją, leży u podstaw obrazu / wizji świata. Podmiot doświadcza i konceptualizuje rzeczywistość. Obraz językowy zawsze nosi piętno i „ślady” swego twórcy, oddaje jego mentalność (zob. Bartmiński, Pajdzińska 2008; Bartmiński 2008a).

13. Operacjonalizacja instrumentarium LEK. Zestaw tych narzędzi analitycznych LEK, zaproponowany wstępnie w roku 1980 w zeszycie próbnym słownika stereotypów językowych (SLSJ) i rozbudowywany systematycznie w kolejnych latach, został najbardziej konsekwentnie i na dużą skalę zastosowany w Stowniku stereotypów i symboli ludowych (SSiSL), którego tom II, cz. 1 (Zboża) wyszedł w roku 2017 - oraz w Leksykonie aksjologicznym Stowian i ich sqsiadów, którego trzy pierwsze tomy: DOM, PRACA i HONOR - wydano w latach 2015-2017 (LASiS 1, 3 i 5).

Niektóre teoretyczne aspekty metodologii LEK podejmowały publikacje książkowe J. Bartmińskiego (2006, 2007, 2014) i S. Niebrzegowskiej(-Bartmińskiej) (1995, 2007) oraz 
opublikowane w formie książkowej rozprawy doktorskie: Marzeny Marczewskiej (2002), Iwony Bielińskiej-Gardziel (2009), Grzegorza Żuka (2010), Moniki Grzeszczak (2015), także w pewnym zakresie Małgorzaty Brzozowskiej (2009) i Marty Nowosad-Bakalarczyk (2009). Wymienić należy także rozprawy habilitacyjne Jana Adamowskiego (1999), Jadwigi Kozłowskiej-Dody (2015) i Joanny Szadury (2017), korzystające z metodologii LEK i poniekąd ją wzbogacające. Najpełniejszą informację o dorobku LEK do roku 2009 przynosi bibliografia Beaty Maksymiuk-Pacek i S. Niebrzegowskiej-Bartmińskiej (2009) i artykuły S. Niebrzegowskiej-Bartmińskiej (2004b, 2009, 2013, 2014, 2015, 2017).

Najważniejszym długofalowym zadaniem realizowanym przez zespół LEK jest Słownik stereotypów $i$ symboli ludowych (SSiSL 1996-). Jego metodologia została z pewnymi modyfikacjami przyjęta przez międzynarodowy zespół, opracowujący od roku 2012 semantykę nazw wartości w ramach konwersatorium EUROJOS i wydający Leksykon aksjologiczny Słowian i ich sasiadów (zob. LASiS 1, 3 i 5). Do szczegółowych badań analitycznych w ramach Konwersatorium EUROJOS wybrano 5 hasel:

- DOM i EUROPE, bo mówimy o Europie jako „wspólnym domu”;

- PRACE, bo od niej zależą sukcesy i klęski życiowe młodych ludzi;

- WOLNOŚĆ, bo jest sztandarową wartością naszej części świata;

- GODNOŚĆ i HONOR, bo sięgają źródeł kultury europejskiej i są wpisane do Powszechnej deklaracji praw człowieka uchwalonej przez ONZ w 1948 roku.

14. Sposób eksplikowania konceptów - odpowiadający postulatom etnolingwistyki kognitywnej - można znaleźć we wspomnianych tomach LASiS (1, 3 i 5), syntetycznie też m.in. w opracowaniu „domu europejskiego” (Bartmiński 2018b).

W tym miejscu przedstawię ten problem na przykładzie $\boldsymbol{P R A C Y}$.

Opieram się na tomie LASiS 3 wydanym w roku 2016 pod red. J. Bartmińskiego, M. Brzozowskiej i S. Niebrzegowskiej-Bartmińskiej. Zawiera on definicje kognitywne (kulturowe) konceptu PRACA w 14 językach słowiańskich (polski i czeski, rosyjski, białoruski i łemkowski, z południowych - bułgarski, serbski i chorwacki) i niesłowiańskich - w tym zarówno sąsiadów Słowian bliskich (litewski), jak dalszych (grecki, angielski, francuski i portugalski), a nawet odległych (japoński i trzy języki afrykańskie: suahili, tamaszek i hausa).

Artykuły zostały skomponowane wedle podobnego schematu; po ogólnym wprowadzeniu i krótkim przeglądzie badań nad pracą oraz podaniu podstawy materiałowej opisu następuje cześć zasadnicza, omówienie pracy w świetle danych systemowych (definicje słownikowe 
leksykalnych eksponentów konceptu PRACA; etymologia nazw PRACY; kategorie nadrzędne (hiperonimy), kohiponimy PRACY i opposita; synonimy, derywaty i frazeologizmy), ankietowych i tekstowych (przysłowia; teksty literatury pięknej; teksty prasowe i publicystyczne; dane korpusowe) - ta część artykułu odpowiada ujęciu „separacyjnemu”, jak je określa S. Niebrzegowska-Bartmińska (2015).

Podam w skrócie niektóre wyniki analiz w porządku przyjętym w artykułach $\mathrm{w}$ tomie PRACA, zwracając uwagę na to, co łączy poszczególne języki.

Nazwy PRACY i ich etymologia. W językach europejskich koncept PRACY ma różne wykładniki leksykalne, których etymologia wiele mówi o konceptualizacji pracy jako pewnego rodzaju działań.

Etymologia pol. słowa praca jest niepewna, natomiast roboty i trudu $\mathrm{w}$ miarę przejrzysta. Robota ma ten sam rdzeń co parobek 'sługa, służący', stpol. roba 'niewolnica' i ros. rab 'niewolnik'; czeska robota znaczy 'pańszczyzna'. W języku starocerkiewnosłowiańskim robota/rabota znaczyła 'niewola, niewolnictwo'. Odpowiednik łaciński labor oznaczał nie tylko 'pracę', ale również 'cierpienie, bolesny wysiłek'. Zbieżne wyniki daje analiza etymologiczna słowa trud, które w języku polskim oznacza 'ciężką pracę, wysiłek', a w rosyjskim jest podstawowym wykładnikiem leksykalnym konceptu PRACA; trud w języku cerkiewno-słowiańskim funkcjonował w znaczeniu 'wysiłku fizycznego, cierpienia i przeszkód', 'lęku i smutku'. W etymologicznym związku z trudem pozostają litew. triūsas 'praca, nadmiar zajęć' i łac. trūdō 'uderzam, pcham, pędzę gwałtownie'; a wszystkie te formy są sprowadzane do pie. rdzenia *ter- w znaczeniu 'trzeć, rozcierać' (Boryś 2005: 644). Związek pracy z cierpieniem potwierdza etymologia franc. travail i hiszp. trabajo w obu tych słowach znaczenie pracy jest łączone z 'ciężarem', oba słowa pozostają w związku etymologicznym z łac. trabalium 'ciężar'. Jak zatem wynika $\mathrm{z}$ etymologii nazw pracy w pierwotny sens konceptu PRACY wpisane są znaczenia przymusu, cierpienia i podporządkowania komuś, niewolnictwa. Swietłana Tołstojowa zwróciła uwagę na to, że leksem ros. trud 'praca' wchodzi w związki semantyczne nie tylko z leksemami nazywającymi ból i cierpienie, ale też poród i życie pozagrobowe, ogarnia więc swoją semantyką całą życiową drogę człowieka - „od narodzin w trudzie i mękach przez nieprzerwany trud całego życia do ostatnich mąk śmiertelnych” (Tolstaja 2008: 120).

Zuzanna Topolińska, która dokonała systematycznej analizy semantycznej kontynuantów pięciu prasłowiańskich rdzeni *děti, *orb- , *port'-, *prav-, *trud- nazywających pracę 
(rdzenie te są obecne w pol. leksemach działać, robić, pracować, sprawiać, trudzić się), doszła do wniosku, że w rozwoju historycznym najważniejsza jest różnica między prostą pracą fizyczną, która kojarzy się przede wszystkim z wysiłkiem, zniewoleniem, męką, cierpieniem, a pracą twórczą, zorganizowaną społecznie:

Od pracy w sensie oswajania realnego świata przyrody, pracy rolnika, hodowcy itp. przechodzimy sukcesywnie do pracy w zorganizowanej wspólnocie, pracy „dla kogoś”, pracy zinstytucjonalizowanej, pracy zarobkowej, przyczem od samego początku pojawia się wątek kreacji, rzemiosła artystycznego, inwencji technicznej i technologicznej. Innymi słowy: szerzy się pole semantyczne, krzyżują się asocjacje związane z wielorakim pragmatycznym kontekstem użycia pojęcia pracy i rośnie frekwencja użyć w nowych, „uszlachetnionych”, kontekstach”.

(Topolińska 2018: 349)

W definicjach słownikowych nazw pracy w poszczególnych językach liczba wyróżnianych znaczeń jest zmienna. W Uniwersalnym słowniku języka polskiego pod red. Stanisława Dubisza (2003) słowu praca przypisano 7 znaczeń:

1) 'celowa działalność człowieka, zmierzająca do wytworzenia określonych dóbr materialnych lub kulturalnych, będąca podstawą egzystencji i rozwoju społeczeństwa, działanie, robienie czegoś, robota, wykonywany zawód’;

2) 'wytwór celowej działalności człowieka, zwłaszcza w dziedzinie nauki lub kultury’;

3) 'zajęcie, zatrudnienie jako źródło zarobku; posada, zarobkowanie’;

4) 'funkcjonowanie, aktywność organizmu, organów człowieka, zwierzęcia';

5) 'funkcjonowanie, bycie w ruchu jakiejś maszyny, jakiegoś urządzenia';

6) pot. 'instytucja, w której się pracuje zarobkowo; zakład pracy, firma';

7) fiz. 'jedna z podstawowych wartości fizycznych, określająca wartość energii potrzebnej do przemieszczania ciała materialnego w przestrzeni [...]'.

W słownikach innych języków wyróżnia się znaczeń od trzech (np. w języku litewskim i niemieckim) do ośmiu we włoskim. Różnice polegają na odmiennych zasadach definiowania i zaczynają się w momencie ustalania kategorii nadrzędnej (hiperonimu).

Hiperonimem nazw PRACY jest działanie / działalność, urobione od czasownika działać, który jest znany wszystkim językom słowiańskim. Nieco węższe znaczenie od działania ma zajęcie / zajmowanie się czymś, ale oba dają się zdefiniować za pomocą jeszcze ogólniejszej kategorii robienia czegoś, czynności, aktywności. Mamy więc do czynienia ze strukturą kilkupoziomową: 
poziom I: czynność, aktywność - wspólny mianownik 'robienie czegoś';

poziom II: działanie, zajęcie - wspólny mianownik 'robienie czegoś + celowe';

poziom III: praca, robota - wspólny mianownik: 'robienie czegoś + celowe $+\mathrm{z}$

wysiłkiem + z nastawieniem na rezultat');

Bazą słowotwórczą działania było dzianie się mające ogólne znaczenie 'zdarzenia, odbywania się'. Pochodne słowa to: dzieło 'rzecz wykonana', dzielny pierwotnie 'czynny, energiczny' (znamienna różnica: w polskim dzielny znaczy tyle co 'waleczny', w czeskim delný to 'pracowity'), dzieje 'historia' itp.

Kohiponimami - czyli nazwami innych działań, zajęć i form aktywności poza pracą są: gry i zabawy, odpoczynek, sport, spacery, wycieczki (i szerzej: turystyka); nauka, czytanie zajęcia dydaktyczne, modlitwa. Wskazanie kohiponimów jest równoznaczne z ustanowieniem różnicy, kontrastu i w prosty sposób prowadzi do opozycji.

Niewątpliwie w układach antonimicznych funkcjonują praca i bezrobocie, praca i odpoczynek, praca i próżnowanie (lenistwo), praca i święto, rozrywka, luz. Kontekstowym antonimem pracy w przysłowiach może być też mówienie, jak w brus. Bolsz rabi, a mieńsz hawary (Więcej rób, mniej mów); serb. Lasno je govoriti, al' je teško tvoriti (Łatwo mówić, trudno zrobić).

Synonimika pracy w Dystynktywnym słowniku synonimów Alicji Nagórko, Marka Łazińskiego i Hanny Burkhardt (2004) obejmuje krótką serię: praca, zajęcie, zatrudnienie, robota, ekspresywne słowa fucha pot., lekcew. 'nielegalna robota wykonywana w godzinach pracy' i chattura środ., lekcew. 'mało ambitna praca zarobkowa artysty'. W istocie synonimika pracy jest bardzo bogata, daje się pogrupować odpowiednio do sześciu wyróżnianych znaczeń leksemu nazywającego pracę (wzorowo zrobiono to w PSWP pod red. Haliny Zgółkowej, 2001):

do znaczenia (1) 'działania wymagające wysiłku, wykonywane w jakimś celu': aktywność, działanie, harówka, katorga, kierat, krwawica, męczarnia, mordęga, mozót, obowiązki, orka, pańszczyzna, pot, robota, siódme poty, służba, trud, wysiłek, zachrzan, zapieprz, zajęcie, zatrudnienie, zasuw, znój;

do znaczenia (2) 'rezultat działań': dorobek, dysertacja, dzieło, (lekcew.) elaborat, elukubracja, esej, monografia, omówienie, opracowanie, produkcja, publikacja, rezultat, rozprawa, studium, szkic, tekst, twór, twórczość, utwór, wynik pracy, (pot., lekcew.) wypociny, wytwór;

do znaczenia (3) 'zajęcie, źródło utrzymania': ciepła posadka, angaż, engagement, etat, fotel, fucha, funkcja, godność, miejsce, posada, pozycja, robota, stanowisko, (pot. pogardl.) 
stołek, synekura, zajęcie, zatrudnienie; do negatywnie nacechowanych synonimów pracy w tym znaczeniu w ostatnich latach doszła jeszcze śmieciówka, umowa śmieciowa, którymi to wyrazami potocznie określa się umowy na czas określony, niewymagające ubezpieczenia zdrowotnego (Jak pracodawcy przestanie się opłacać zatrudniać ludzi na śmieciówkach, to jest większa szansa, że da pracownikowi etat);

do znaczenia (4) 'ogół działań wykonywanych wspólnie': aktywność, czynności, działalność, działania, postepowanie, robota;

do znaczenia (5) 'funkcjonowanie organizmu': aktywność, czynność, działanie, funkcjonowanie, trud, wysiłek;

do znaczenia (6) 'miejsce, instytucja, w której się pracuje': fabryka, firma, instytucja, miejsce pracy, przedsiębiorstwo, zakład.

Zwraca uwagę bogactwo pejoratywnych synonimów pracy w jej podstawowym znaczeniu (1) 'działania wymagające wysiłku, wykonywane w jakimś celu' potoczne odwalić i chałturzyćl odstawić chatturę; harować, zasuwać 'wykonywać ciężką pracę pod przymusem', wulg. zapieprzać i zapierdalać.

Najwięcej synonimów w języku polskim odnosi się do pracy ciężkiej.

Derywaty i frazeologizmy utrwalają kategorię wykonawcy pracy: pol. robotnik $i$ pracownik; w językach litewskim, rosyjskim, ukraińskim, czeskim i bułgarskim specjalnymi nazwami obdarzani są wykonawcy „lubiący/miłujacy” pracę i „sposobni” do pracy: ukr. pracelub, pracelubnyj, czes. prácemilovný; bułg. rabotosposoben. Z dystansem - używając pożyczki z ang. workaholic - mówi się o ludziach, którzy pracują ponad miarę, zatracają umiar w pracy: pol. pracoholik/pracoholiczka; bułg.rabotoholik, chorw. radoholičar.

Osoby pracowite, lubiące pracę kojarzone są z pszczołą (jeśli praca przynosi oczywisty pożytek), z mrówką (jeśli praca wykonywana jest z dużą pilnością i starannością), człowiek, który pracuje ciężko porównywany jest do konia, wołu, muła (w hiszp. trabajar como una mula), sporad. psa (wł. lavorare come un cane). Ogólnie, praca trudna i ciężka porównywana jest do pracy zwierzęcia (wł. lavorare come una bestia 'harować jak zwierz').

Zbiorowego, kolektywnego wykonawcę utrwala leksyka tworzona przy użyciu przedrostka wspót-, łączonego z czasownikiem pracować (pol. wspótpracować, wspótpracownik, wspótpracownica; przy tym chodzi o działania o charakterze raczej umysłowym niż fizycznym.

Utrwalone językowo są rozróżnienia pracodawcy i pracobiorców, pracy fizycznej i wyżej wartościowanej - pracy umysłowej. 
Terminologia dotycząca jednostek czasu pracy typu pol. roboczogodzina, dniówka; organizacji pracy ujmowanej w kodeksy prac, regulowanej przez prawo pracy, umowy o prace, oferty pracy, rynek pracy, medycyne pracy itd. ma wymiar międzynarodowy, jest kalkowana z języka do języka.

Utrwala się językowo narzędzie pracy, wyróżniając narzędzie elementarne, jakim jest ręka ludzka: ros. rucznoj trud; pol. prace ręczne; hiszp. trabajo manual. Pamięć o ręce jako podstawowym narzędziu pracy poświadczają takie frazeologizmy, jak pol. być czyjąś prawa ręka 'być czyimś głównym pomocnikiem', mieć ręce pełne roboty 'mieć bardzo dużo pracy', złota raczka, mieć złote ręce 'posiadać umiejętność fachowego wykonywania wszystkiego', robota pali się komuś $w$ rękach 'ktoś pracuje bardzo szybko i efektywnie'; cenione są przedmioty ręcznej roboty. Można też zakasać rękawy 'z zapałem rozpocząć pracę' i urobić sobie ręce po łokcie 'zrujnować sobie zdrowie ciężką pracą', ale też mieć dwie lewe ręce 'nie potrafić niczego zrobić'.

Badanie eksperymentalne polegało na przeprowadzeniu ankiety otwartej, w której respondenci odpowiadali jedno pytanie: Co wedle ciebie stanowi o istocie prawdziwej pracy? Użycie w pytaniu modyfikatora „prawdziwy” miało kierować uwagę na stronę wyobrażeniową, a nie przedmiotową pracy, na to, jak praca jest postrzegana, a nie na to, jaka jest typowa praca w realnej rzeczywistości. Odpowiedzi każdorazowo udzielała podobna liczebnie grupa studencka (z założenia miało to być przynajmniej 100 osób, dobieranych według zasad równowagi płci (po połowie kobiety i mężczyźni) i zróżnicowania typów kształcenia (wydziały ścisłe i humanistyczne). Udało się przeprowadzić ankietę dla dziewięciu języków (Zob. NWwJE 2017).

W środowisku studentów polskich ankietę na temat pracy przeprowadzono trzykrotnie w roku 1990, 2000 i 2010 w Lublinie. Pozwoliło to pokazać nie tylko pojmowanie pracy przez młodą generację Polaków, ale też zachodzące w przeciągu 20 lat pewne zmiany: nastąpił spadek rangi aspektu społecznego pracy (tworzenie wspólnoty), także aspektu etycznego, mniej istotna okazuje się też jakość pracy. Ważniejszy staje się zarobek. Respondenci zwracali też uwagę na stronę psychologiczną pracy, w tym zwłaszcza na możliwość czerpania z pracy satysfakcji, przyjemności. Za ważne uznawali zaangażowanie pracownika (pasję) i wysiłek/trud wkładany w to, co się robi.

Wybiórczo wykorzystano dane tekstowe - uwzględniono przysłowia, publicystykę i elektroniczne korpusy językowe. 
Ukoronowaniem analiz cząstkowych, „separacyjnych” jest ujęcie „holistyczne”, syntetyczna definicja kognitywna i rekonstrukcja profili bazowego wyobrażenia pracy funkcjonujących w społecznej komunikacji, we współczesnych dyskursach narodowych. Definicja kognitywna pracy w języku polskim może przybrać kształt następujący ${ }^{19}$ :

PRACA

1. jest (zawsze) działaniem / zajęciem [różnym od zajęć takich, jak nauka, zabawa, sport, modlitwa...].

2. (zawsze) koniecznością życiową [por. np. przysł. Bez pracy żyją ptacy].

3. (zawsze) wykonawcą pracy jest człowiek [por. leksemy pracownik, robotnik; pracodawca, pracobiorca; człowieka może zastąpić robot, ale mówienie o pracy maszyn polega na rozszerzeniu metaforycznym słowa praca].

4. (zawsze) ma określony cel [por. zapracowat na coś; wypracowat/ opracowat coś; przysł. Praca ludzi wzbogaca itp....].

5. (zawsze) wymaga wysitku [ta cecha pracy jest najsilniej utrwalona w etymologii i synonimach: trud, harówka, męczarnia itp.; w derywatach: napracować się/ narobić się, spracować się; fraz.: praca uciążliwa, wyczerpujaca; pracować jak wół / koń; zapracować się na śmierć itp. ...]

6. (zawsze) efektem 1 pracy jest jakiś przedmiot lub wartość [por. derywaty: wyrób, praca ‘dzieło', robótka; opracowanie, wypracowanie; dorobek...].

7. (zwykle) efektem 2 pracy jest wynagrodzenie [por. zarobek, zapłata (za pracę najemna; fraz. robić / zrobić kasę / pieniadze; ale: praca społeczna 'bez wynagrodzenia'; przysł. Jaka praca taka płaca...].

8. (sądzi się, że) jest moralnym obowiązkiem człowieka [por. przysł. Bez pracy nie ma kołaczy; Kto nie pracuje ten nie je...].

9. może być fizyczna i/lub umysłowa por. robol; praca magisterska, doktorska itp....].

10. może być męcząca/przyjemna, lekka/ciężka /... [por. praca męcząca, przyjemna; praca lekka, ciężka...].

11. może być zespołowa / indywidualna [por. fraz. prace zbiorowe; polowe...].

12. może być zlecona / dobrowolna [por. prace zlecone...].

13. może być wykonywana dobrowolnie lub z przymusu [por. fraz. umowa pracy, praca niewolnicza, nakaz pracy...].

14. może dawać satysfakcję, sprawiać przyjemność / nie sprawiać przyjemności.

15. (zwykle) korzysta z narzędzi [por. rękodzieło; praca maszynowa ...] 
16. (zwykle) odbywa się w określonym miejscu [por. pracownia, fraz. miejsce pracy; praca biurowa, wyróżniane są: praca domowa (prowadzenie domu jako praca), praca chałupnicza, roboty polowe; dom pracy twórczej, obóz pracy...].

17. (zwykle) odbywa się w określonym czasie [por. fraz. czas pracy, godziny pracy, dni robocze, sobota pracująca; praca po godzinach, praca na czarno; spory o ośmiogodzinny dzień pracy, o skrócenie tygodnia pracy...].

18. (zwykle) odbywa się na określonych zasadach [por. fraz. bezpieczeństwo i higiena pracybhp; warunki pracy, inspekcja pracy, kodeks pracy, urzad pracy, sad pracy...].

Status ontologiczny podanych cech definicyjnych pracy jest zróżnicowany. Jedne cechy są przypisywane pracy stale, a inne tylko fakultatywnie. $\mathrm{Z}$ tego powodu $\mathrm{w}$ proponowanym wyżej zapisie zastosowano „modyfikatory” typu: „zawsze”, „zwykle”, „może być”. Taka „holistyczna” definicja kognitywna polskiej PRACY, ograniczona do składników mających „certyfikację”, tzn. takich, dla których udaje się podać „dowody językowe”, pozwala wskazać podstawowe parametry (fasety, wymiary), do których należą: [wykonawca], [czynność], [cel działania], [wysiłek], [efekt / wytwór], [zarobek / wynagrodzenie]. Modelowy zapis bazowego wyobrażenia PRACY może przybrać postać zdania: KTOŚ - DZIAŁA - CELOWO POKONUJĄC TRUDNOŚCI - OSIĄGA EFEKT - OTRZYMUJE WYNAGRODZENIE. Słabszą pozycję (rzadziej uwzględnianą w definicjach i użyciach tekstowych) mają fasety takie, jak: [narzędzie], [jakość działania / cechy], [etos - obowiązek], [czas], [miejsce], [warunki]. Wszystkie fasety uporządkowane w nieprzypadkowy sposób składają się na „strukturę kognitywną” pojęcia PRACY.

W komunikacji społecznej bazowy koncept PRACY funkcjonuje w wariantach kontekstowych, jest różnie profilowany. W polskiej przestrzeni społecznej można wyróżnić 5 profili pojęcia PRACY.

Profil tradycyjny (ludowy), w którym prototypem pracy jest uprawa roli, efektem tej pracy jest chleb i dostatek (niekiedy bogactwo). Praca miała wymiar sakralny, ciężki trud był (i jest) jej atrybutem nieodłącznym; narzędziem pracy był pług (wcześniej mityczna już dziś socha), sierp i kosa; mniej ważny był zarobek, wynagrodzenie pieniężne. Człowiek był podporządkowany pracy. Praca umysłowa nie była (i nie jest) ceniona.

Profil religijny, w którym praca jest obowiązkiem moralnym i koniecznością jako kontynuacja twórczego dzieła Boga; praca służy samorealizacji człowieka i tworzeniu 
wspólnoty ludzkiej. Aspekty fizyczny i umysłowy są taktowane integralnie, praca ma podstawę w godności osoby ludzkiej, jej efektem jest nie tylko produkt, ale też wartości intelektualne i duchowe, służące człowiekowi.

Pragmatyczny profil przedsiębiorcy (pracodawcy) - praca jest procesem podlegającym racjonalizacji w kategoriach efektów ekonomicznych towaru i ceny, kupna i sprzedaży. Praca jest towarem. Liczy się efekt pracy w postaci wytworzonego produktu i jego cena. Kluczową role grają: koszty pracy (wkład kapitału, wynagrodzenie) wydajność pracy i warunki organizacji pracy (czas i miejsce, kodeks pracy, prawo pracy, ergonomia).

Pragmatyczny profil pracownika (pracobiorcy) - liczy się wynagrodzenie, możliwość indywidualnego rozwoju i dokształcania się, ważny jest jej aspekt podmiotowy. Oczekuje się, że praca będzie atrakcyjna, niemęcząca, atmosfera w pracy przyjazna. Podkreśla się nieustanne niebezpieczeństwo wyzysku pracy, dlatego potrzebne są związki zawodowe, broniące praw pracowniczych.

Profil bezrobotnego. Praca jest wartością, dobrem pożądanym i trudno osiągalnym, ale negocjowanym: nie każda praca, nie każde wynagrodzenie, nie każde warunki są akceptowane.

\section{Przypisy}

\footnotetext{
${ }^{1}$ Dziękuję doktorowi Władysławowi Chłopickiemu za zaproszenie do wygłoszenia tego wystąpienia na konferencji Tertium „Język trzeciego tysiąclecia X” OTWARTOŚĆ w badaniach językowych, kulturowych i przekładowych. OTWARTOŚĆ w nauce i dydaktyce”, Kraków 21-23.03.2018 r.

${ }^{2}$ Pisałem o tym w artykule: Bartmiński 2008.

${ }^{3}$ Z perspektywy 25 lat Piotr Żmigrodzki uznał, że ,tekst [ten] zapoczątkował pewien nurt polskiej dyskusji metaleksykograficznej” i że „dopiero w 2000 roku ukazał się Inny słownik języka polskiego, który przyniósł definicje - w ogólnym zarysie - spełniające [...] postulaty Bartmińskiego, a w każdym razie zdecydowanie zrywające z wszechobecnym we wcześniejszej polskiej leksykografii scjentyzmem" (Żmigrodzki 2010; 33-34). ${ }^{4}$ Ten program został po latach systematycznie wyłożony przez Swietłanę Tołstojową w artykule „Постулаты московской этнолингвистики" (Tolstaja 2006).

${ }^{5}$ Używam formuł stosowanych przez autorów rosyjskich - Anatolija Żurawlowa i Eleny Berezowicz.

${ }^{6}$ Ciekawostka. Dwa pierwsze tomy serii Język a Kultura wydał Uniwersytet Wrocławski - uwaga: jeszcze poza obowiązującą wówczas cenzurą - w wewnętrznej niskonakładowej serii z biało-czerwonym paskiem, ale dwa lata później zostały już „legalnie” przedrukowane w nowej szacie graficznej w tzw. „białej serii”. Jest to szczegół o tyle godny uwagi, że - jak po latach dowiedziałem się z dokumentacji w IPN - projekty badań nad językowym obrazem świata i zaplanowanym już wtedy słownikiem wartości zaniepokoiły ówczesne władze komunistyczne i na moje kontakty $\mathrm{z}$ Wrocławiem w latach 80 . nałożono podsłuchy!

7 Zob. Burzyńska-Kamieniecka, Anna (red.) Język a Kultura, t. 26, Kulturowe uwarunkowania zachowań językowych. Tradycja i zmiana (2016). Wrocław: Wyd. UWr. Tom zawiera materiały z XLIII konwersatorium w Karpaczu, 30 V - 1 VI 2014 roku. Podsumowanie 37 spotkań (do roku 2003) przedstawili Bartmiński i Dąbrowska (2004).

${ }^{8}$ Zawartość 25 tomów „czerwonej serii” przybliża opracowanie Agnieszki Boguty (2010).

${ }^{9} \mathrm{~W}$ szczególności polega to na tym, że język jest narzędziem wartościowania; jest obiektem podlegającym wartościowaniu, a przed wszystkim jest przekaźnikiem wartości i informatorem o wartościach (Bartmiński 2003). Jadwiga Puzynina te złożone relacje ujmuje syntetyczną formułą „Język wartości” (1992).
} 
${ }^{10}$ Zob. też m.in.: Anusiewicz J., Dąbrowska A. (red.) 2000; Marczewska 2002: 18-30; Bartmiński 2006: 11-21; Guz 2012; Głaz, Danaher, Lozowski (red.) 2013; Gicala 2018.

${ }^{11}$ Zob. też m.in.: Bartmiński J., Panasiuk J., 1993; SSiSL 1996-2017; Bartmiński 2007; Bielińska-Gardziel 2009.

${ }^{12}$ Zob. też m.in.: SLSJ 1980; SSiSL 1996-2017; Niebrzegowska-Bartmińska 2007: 23-31, 2017; Brzozowska 2009; Żmigrodzki 2010; Bartmiński 2013, 2018c; LASiS 2015-2017.

${ }^{13}$ Zob też m.in.: Niebrzegowska-Bartmińska 2015; Grzeszczak 2015; Bartmiński 2018a.

${ }^{14}$ Zob. też. Niebrzegowska 1996. W kolejności wydano też poświęcone wartościom tomy „,zerwonej serii” (tworząc w jej ramach podserię) pt. Wartości w językowo-kulturowym obrazie świata Stowian i ich sq̨siadów (WJOSS) 1-4. Poza tą serią opublikowano w Wydawnictwie UMCS tomy: JWP 2006; LASiS 1, 3 i 5. Nakładem Instytutu Europy Środkowo-Wschodniej wydano tom Pojęcie ojczyzny we współczesnych językach europejskich, red. J. Bartmiński (1993). W Wydawnictwie Państwowej Wyższej Szkoły Wschodnioeuropejskiej w Przemyślu ukazał się tom Nazwy wartości w językach europejskich. Raport z badań empirycznych, red. I. Bielińska-Gardziel, M. Brzozowska, B. Żywicka (2017).

${ }^{15}$ M.in. Kreowanie świata w tekstach, red. A. M. Lewicki, R. Tokarski (1995); Językowa kategoryzacja świata red. R. Grzegorczykowa, A. Pajdzińska (1996); Tekst. Problemy teoretyczne, red. J. Bartmiński, B. Boniecka (1998); Tekst. Analizy i interpretacje, red. J. Bartmiński, B. Boniecka (1998); Przeszlość w językowym obrazie świata, red. A. Pajdzińska, P. Krzyżanowski (1999); Semantyka tekstu artystycznego, red. A. Pajdzińska, R. Tokarski (2001); Manipulacja w języku, red. P. Krzyżanowski, P. Nowak (2004), Przestrzeń w języku i w kulturze (1-2), red. J. Adamowski (2005); Bariery i pomosty w komunikacji językowej Polaków, red. J. Bartmiński, U. Majer-Baranowska (2005); Kreowanie światów w języku mediów, red. P. Nowak, R. Tokarski (2007); Relatywizm w języku i kulturze, red. A. Pajdzińska, R. Tokarski (2010); Jezzyk IV Reczypospolitej, red. M.Czerwiński, P. Nowak, R. Przybylska (2010); Narracyjność języka i kultury. Literatura i media, red. D. Filar, D. Piekarczyk (2013); red. D. Filar, D. Piekarczyk (2014); Historia mówiona w świetle nauk humanistycznych i społecznych, red. S. Niebrzegowska-Bartmińska, J. Szadura, M. Szumiło przy udziale J. Kłapcia (2014); Działania na tekśsie $w$ edukacji szkolnej i uniwersyteckiej; Działania na tekście: Przekład - redagowanie - ilustrowanie, red. S. Niebrzegowska-Bartmińska, M. Nowosad-Bakalarczyk, T. Piekot (2015).

${ }^{16}$ Zob. w bibliografii pod Język a Kultura.

${ }^{17}$ Więcej w: Bartmiński 2007, 2016.

${ }^{18} \mathrm{~W}$ kręgu etnolingwistyki lubelskiej jego odpowiednikiem jest stereotyp rozumiany za Putnamem (1975) jako społeczne wyobrażenie przedmiotu. Takie rozumienie stereotypu leży u podstaw Stownika stereotypów i symboli ludowych (SSiSL 1996-2017).

${ }^{19}$ Prezentując w skrócie koncept PRACA w języku polskim, korzystam z artykułu Bartmińskiego i BielińskiejGardziel 2015.

\section{Bibliografia}

Abramowicz, Maciej, Jerzy, Bartmiński, (red.) (1989) Tekst ustny - texte oral: struktura i pragmatyka, problemy systematyki, ustność w literaturze. Wrocław: Wiedza o kulturze.

Abramowicz, Maciej, Jerzy, Bartmiński, Wojciech, Chlebda (2009) „Językowo-kulturowy obraz świata Słowian na tle porównawczym. Założenia programu „A””. [W:] Jerzy Bartmiński (red.) Etnolingwistyka, t. 21. Lublin: Wydawnictwo UMCS; 341-342.

Adamowski, Jan, Antoni (1999) Kategoria przestrzeni w folklorze. Studium etnolingwistyczne. Lublin: Wydawnictwo UMCS.

Adamowski, Jan, Antoni (red.) (2005) Przestrzeń w języku i w kulturze (1-2). Lublin: Wydawnictwo UMCS. Anusiewicz, Janusz (1988) „Kulturowa teoria języka. Zarys problematyki”. [W:] Janusz Anusiewicz, Jerzy Bartmiński (red.) Język a Kultura, t. 1. Wrocław: Wydawnictwo Uniwersytetu Wrocławskiego; 21-46. [Przedruk jako: Janusz Anusiewicz, Jerzy Bartmiński (red.) (1991) Język a Kultura, t. 1. Podstawowe pojęcia i problemy. Wrocław: Wiedza o kulturze; 17-30].

Anusiewicz, Janusz (1994) Lingwistyka kulturowa. Zarys problematyki. Wrocław: Wydawnictwo Uniwersytetu Wrocławskiego. 
Anusiewicz, Janusz, Anna, Dąbrowska (red.) (2000) Język a Kultura, t. 13, Językowy obraz świata i kultura.

Wrocław: Wydawnictwo Uniwersytetu Wrocławskiego.

Anusiewicz, Janusz, Anna, Dąbrowska, Michael, Fleischer (2000) Językowy obraz świata i kultura. Projekt koncepcji badawczej. [W:] Janusz Anusiewicz, Anna Dąbrowska (red.) Język a Kultura, t. 13, Językowy obraz świata i kultura. Wrocław: Wydawnictwo Uniwersytetu Wrocławskiego; 11-44.

Apresjan, Jurij (1994) „Naiwny obraz świata a leksykografia”. [“Native image of the world and lexicography”] (tłum.) Joanna Berej, Anna Pajdzińska [W:] Jerzy Bartmiński (red.) Etnolingwistyka, t. 6. Lublin: Wydawnictwo UMCS; 5-12.

Арутюнова, Нина [Arutjunova, Nina] (red.) (1991) Логический анализ языка. Культурные конщепты. Москва: Наука.

Bartmiński, Jerzy (1973) O języku folkloru. Wrocław: Ossolineum.

Bartmiński, Jerzy (red.) (1980) Stownik ludowych stereotypów językowych. Zeszyt próbny. Wrocław.

Bartmiński, Jerzy (red.) (1981) Pojęcie derywacji w lingwistyce. Lublin: Wydawnictwo UMCS.

Bartmiński, Jerzy (1984) „Definicja leksykograficzna a opis języka”. [W:] Kazimierz Polański (red.) Stownictwo w opisie języka. Katowice: UŚ; 9-21.

Bartmiński, Jerzy (1988a) „Definicja kognitywna jako narzędzie opisu konotacji”. [W:] Jerzy Bartmiński (red.) Konotacja. Lublin: Wydawnictwo UMCS; 169-183.

Bartmiński, Jerzy (1988b) „Konwersatorium „Język a Kultura”. Projekt programu”. [W:] Janusz Anusiewicz, Jerzy Bartmiński (red.) Język a Kultura, t. I. Wrocław: Wydawnictwo Uniwersytetu Wrocławskiego; 7-19. [Przedruk w: Anusiewicz, Janusz, Jerzy Bartmiński (red.) (1991) Język a Kultura, t. 1. Podstawowe pojęcia i problemy. Wrocław: Wydawnictwo Uniwersytetu Wrocławskiego; 9-16].

Bartmiński, Jerzy (1988c) „Słowo wstępne”. [W:] Jerzy Bartmiński (red.) Etnolingwistyka, nr 1. Lublin: Wydawnictwo UMCS; 5-7.

Bartmiński, Jerzy (1990) „Punkt widzenia, perspektywa, językowy obraz świata”. [W:] Jerzy Bartmiński (red.) Językowy obraz świata. Lublin: Wydawnictwo UMCS; 109-127. [przedruk w tomie Bartmiński Jerzy (2006) Językowe podstawy obrazu świata. Lublin: Wydawnictwo UMCS 2006; 76-88].

Bartmiński, Jerzy (red.) (1993a) Pojęcie ojczyzny we wspótczesnych językach europejskich. Lublin: Instytut Europy Środkowo-Wschodniej.

Bartmiński, Jerzy (1993b) „Wprowadzenie”. [W:] Jerzy Bartmiński (red.) Encyklopedia kultury polskiej XX wieku. Wspótczesny język polski. Wrocław: Wiedza o kulturze; 13-23.

Bartmiński, Jerzy (red.) (2001) „Język w kontekście kultury”. [W:] Wspótczesny język polski. Lublin: Wydawnictwo UMCS; 13-22.

Bartmiński Jerzy (red.) (2001) Wspótczesny język polski. Lublin: Wydawnictwo UMCS (V wyd. w roku 2014).

Bartmiński, Jerzy (2003) „Miejsce wartości w językowym obrazie świata”. [W:] Jerzy Bartmiński (red.) Język w kręgu wartości. Lublin: Wydawnictwo UMCS; 59-86.

Bartmiński, Jerzy (2005) „Koncepcja językowego obrazu świata w programie slawistycznych badań porównawczych". [W:] Kwiryna Handke (red.) Studia z Filologii Polskiej i Stowiańskiej, t. 40. Warszawa: PAN; 259-280.

Bartmiński, Jerzy (2006) Językowe podstawy obrazu świata. Lublin: Wydawnictwo UMCS. (Wyd. V w roku 2012). 
Bartmiński, Jerzy (2007) Stereotypy mieszkaja w języku. Studia etnolingwistyczne. Lublin: Wydawnictwo UMCS. (Wyd. II w roku 2009).

Bartmiński, Jerzy (2008a) „Polifoniczność tekstu czy podmiotu? Podmiot w dialogu z samym sobą”. [W:] Jerzy Bartmiński, Anna Pajdzińska (red.) Podmiot w języku i kulturze. Lublin: Wydawnictwo UMCS; 161-183.

Bartmiński, Jerzy (2008b) „Etnolingwistyka, lingwistyka kulturowa, lingwistyka antropologiczna?”. [W:] Anna Dąbrowska (red.) Język a Kultura, t. 20. Wrocław: Wydawnictwo Uniwersytetu Wrocławskiego; 15-33.

Bartmiński, Jerzy (2009) Jörg Zinken (red.) Aspects of Cognitive Ethnolinguistics. Sheffield i Oakville: CT Equinox.

Bartmiński, Jerzy (2013) "The Cognitive definition as a Text of Culture". [W:] Adam, Glaz, David, Danaher, Przemyslav, Lozowski (eds.) The Linguistic Worldview: Ethnolinguistics, Cognition, and Culture. London: Versita; 161-180.

Bartmiński, Jerzy (2014a) Polskie wartości w europejskiej aksjosferze. Lublin: Wydawnictwo UMCS.

Bartmiński, Jerzy (2014b) „Narracyjny aspekt definicji kognitywnej”. [W:] Dorota Filar, Dorota Piekarczyk (red.) Narracyjność języka i kultury. Lublin: Wydawnictwo UMCS; 99-115.

Bartmiński, Jerzy (2015) „Perspektywa semazjologiczna I onomazjologiczna w badaniach językowego obrazu świata”. [W:] Poradnik Językowy, nr 1. Warszawa; 14-29.

Bartmiński, Jerzy (2016) „Słowa klucze, kulturemy, koncepty kulturowe”. [W:] Przegląd Humanistyczny, nr 3. Warszawa: Wydawnictwa Uniwersytetu Warszawskiego; 21-29.

Bartmiński, Jerzy (2018a) O profilowaniu pojęć z punktu widzenia etnolingwistyki kognitywnej. [W:] Agnieszka Libura, Daria Bębeniec, Hubert Kowalewski (red.) Dociekania kognitywne, Kraków: Universitas; 13-48.

Bartmiński, Jerzy (2018b) Język w kontekście kultury, czyli co dziś znaczy metafora ,europejski dom”? Katowice: Wydawnictwo Naukowe Śląsk.

Bartmiński, Jerzy (2018c) In the circle of inspiration of Anna Wierzbicka: The cognitive definition - 30 years later (Moskwa, w druku).

Bartmiński, Jerzy, Iwona, Bielińska-Gardziel (2015) „Polski językowo-kulturowy obraz DOMU i jego profile”. [W:] Jerzy Bartmiński, Iwona Bielińska-Gardziel, Beata Żywicka (red.) Leksykon aksjologiczny Stowian $i$ ich sasiadów, t. 1, DOM. Lublin: Wydawnictwo UMCS; 89-121.

Bartmiński, Jerzy, Iwona, Bielińska-Gardziel (2016) „15 lat Konwersatorium EUROJOS”. [W:] Jerzy Bartmiński (red.) Etnolingwistyka, t. 28. Lublin: Wydawnictwo UMCS; 317-326.

Bartmiński, Jerzy, Barbara, Boniecka (red.) (1998a) Tekst. Analizy i interpretacje. Lublin: Wydawnictwo UMCS. Bartmiński, Jerzy, Barbara, Boniecka (red.) (1998b) Tekst. Problemy teoretyczne. Lublin: Wydawnictwo UMCS. Bartmiński Jerzy, Anna, Dąbrowska (2004) „O konwersatorium 'Język a Kultura' - z okazji jubileuszu”. [W:] Jerzy Bartmiński, Stanisława, Niebrzegowska-Bartmińska, Ryszard Nycz (red.) Punkt widzenia w języku i w kulturze. Lublin: Wydawnictwo UMCS; 359-377.

Bartmiński, Jerzy, Monika, Grzeszczak (2014) „Jak rekonstruować kanon wartości narodowych i europejskich?”. [W:] Jerzy Bartmiński (red.) Etnolingwistyka, t. 26. Lublin: Wydawnictwo UMCS; 21-44.

Bartmiński, Jerzy, Urszula Majer-Baranowska (red.) (2005) Bariery i pomosty w komunikacji językowej Polaków. Lublin: Wydawnictwo UMCS.

Bartmiński, Jerzy, Małgorzata, Mazurkiewicz-Brzozowska (red.) (1993) Nazwy wartości: studia leksykalnosemantyczne, t. 1. Lublin: Wydawnictwo UMCS. 
Bartmiński, Jerzy, Stanisława, Niebrzegowska (1998) „Profile a podmiotowa interpretacja świata”. [W:] Jerzy Bartmiński, Ryszard Tokarski (red.) Profilowanie w języku i w tekście. Lublin: Wydawnictwo UMCS; 211223.

Bartmiński, Jerzy, Stanisława, Niebrzegowska-Bartmińska (2009) Tekstologia. Warszawa: Wydawnictwo Naukowe PWN.

Bartmiński, Jerzy, Stanisława, Niebrzegowska-Bartmińska, Ryszard, Nycz (red.) (2004) Punkt widzenia w tekście $i$ w dyskursie. Lublin: Wydawnictwo UMCS.

Bartmiński Jerzy, Anna, Pajdzińska (red.) (2008) Podmiot w języku i kulturze. Lublin: Wydawnictwo UMCS.

Bartmiński, Jerzy, Jolanta, Panasiuk (1993) Stereotypy językowe. [W:] Jerzy Bartmiński (red.) Encyklopedia kultury polskiej XX wieku. Wspótczesny język polski. Wrocław: Wiedza o kulturze; 363-387.

Bartmiński, Jerzy, Ryszard, Tokarski (1993) „Definicja semantyczna: czego i dla kogo?”. [W:] Jerzy, Bartmiński, Ryszard, Tokarski (red.) O definicjach i definiowaniu. Lublin: Wydawnictwo UMCS; 47-61.

Bartmiński, Jerzy, Ryszard, Tokarski (red.) (1993) O definicjach i definiowaniu. Lublin: Wydawnictwo UMCS. Bielińska-Gardziel, Iwona (2009) Stereotyp rodziny we współczesnej polszczyźnie. Warszawa: SOW.

Boguta, Agnieszka (2010) Bibliografia analityczna „czerwonej serii”, 1981-2008. Tomy 1-25. Lublin: Wydawnictwo UMCS.

Boryś, Wiesław (2005) Stownik etymologiczny języka polskiego. Kraków: Wydawnictwo Literackie.

Brzozowska, Małgorzata (2009) Etymologia a konotacja stowa. Lublin: Wydawnictwo UMCS.

Burszta, Wojciech (1986) Język a kultura w myśli etnologicznej. Warszawa: Polskie Towarzystwo Ludoznawcze.

Burzyńska-Kamieniecka, Anna (red.) (2016) Język a Kultura, t. 26, Kulturowe uwarunkowania zachowań językowych. Tradycja i zmiana. Wrocław: Wydawnictwo Uniwersytetu Wrocławskiego.

Chlebda, Wojciech (2010) Etnolingwistyka a leksykografia. Opole: Wydawnictwo Uniwersytetu Opolskiego.

Czachur, Waldemar (red.) (2017) Lingwistyka kulturowa i międzykulturowa. Antologia. Warszawa: Wydawnictwa Uniwersytetu Warszawskiego.

Czerwiński, Maciej, Paweł, Nowak, Renata, Przybylska (2010) Język IV Reczypospolitej. Lublin: Wydawnictwo UMCS.

Dąbrowska, Anna (2017) ,,Język i kultura a glottodydaktyka”. [W:] Dorota Filar, Piotr Krzyżanowski (red.) Barwy stów. Studia lingwistyczno-kulturowe. Lublin: Wydawnictwo UMCS; 125-142.

Dubisz, Stanisław (red.) (2003) Uniwersalny stownik języka polskiego. Warszawa: Wydawnictwo Szkolne PWN. Etnolingwistyka (1988-2018) (red.) Jerzy Bartmiński, t. 1-30. Lublin: Wydawnictwo UMCS.

Gębal, Przemysław (2010) Dydaktyka kultury polskiej w kształceniu językowym cudzoziemców. Podejście porównawcze. Kraków: Universitas.

Gicala, Agnieszka (2018) Przekładanie obrazu świata. Językowy obraz świata w teorii i praktyce przekładu artystycznego. Kraków: Universitas.

Głaz, Adam, David, Danaher, Przemysław, Łozowski (eds.) (2013) The Linguistic Worldview: Ethnolinguistics, Cognition, and Culture. London: Versita.

Głaz, Adam (2015) „Etnolingwistyka daleka i bliska”. [W:] Jerzy Bartmiński (red.) Etnolingwistyka, t. 27. Lublin: Wydawnictwo UMCS; 7-20.

Gryshkova, Nina (2014) „Leksem, pojęcie, stereotyp, koncept, znaczenie, idea - propozycja regulacji terminologicznych". [W:] Iwona Bielińska-Gardziel, Stanisława Niebrzegowska-Bartmińska, Joanna 
Szadura (red.) Wartości w językowo-kulturowym obrazie świata Słowian i ich sqsiadów. 3. Problemy eksplikowania $i \quad$ profilowania pojęć. Lublin: Wydawnictwo UMCS; 21-50.

Grzegorczykowa, Renata (1991) „Rola języka w tworzeniu kultury umysłowej”. [W:] Jerzy Bartmiński (red.) Język a Kultura, t. 1. Lublin: Wydawnictwo UMCS; 61-71.

Filar, Dorota, Dorota, Piekarczyk (red.) ([2013] 2014) Narracyjność języka i kultury. Literatura i media. Lublin: Wydawnictwo UMCS.

Grzegorczykowa, Renata (2011) „Jeszcze o rozumieniu JOS-u w perspektywie badań porównawczych: problem inwariantu pojęciowego". [W:] Jerzy Bartmiński (red.) Etnolingwistyka, t. 23. Lublin: Wydawnictwo UMCS; 217-225.

Grzegorczykowa, Renata, Anna, Pajdzińska (1996) Językowa kategoryzacja świata. Lublin: Wydawnictwo UMCS.

Grzeszczak, Monika (2015) Pojęcie demokracji i jego profilowanie $w$ polskim $i$ niemieckim dyskursie publicznym (1989-2009). Lublin: Towarzystwo Naukowe Katolickiego Uniwersytetu Lubelskiego Jana Pawła II.

Guz, Marzena (2012) Językowy obraz świata u wybranych przedstawicieli lingwistyki niemieckiej, amerykańskiej i polskiej. Poznań: Rys.

Jakobson, Roman (1989) „Wspólny język lingwistów i antropologów”. [W:] Jakobson, Roman, W poszukiwaniu istoty języka. Wybór pism, t. 1. (red.) Maria Renata Mayenowa. Warszawa: PIW; 471-489.

Język a Kultura [seria wydawnicza], t. 1-26, (1988-2016). Wrocław: Wydawnictwo Uniwersytetu Wrocławskiego, obejmuje m.in.:

T. 1. (1991) Janusz Anusiewicz, Jerzy Bartmiński (red.) Podstawowe pojęcia i problemy.

T. 2. (1991) Jadwiga Puzynina, Jerzy Bartmiński (red.) Zagadnienia leksykalne i aksjologiczne;

T. 3. (1991) Jadwiga Puzynina, Janusz Anusiewicz (red.) Wartości w języku i tekście;

T. 4. (1991) Renata Grzegorczykowa, Jerzy Bartmiński (red.) Funkcje języka i wypowiedzi;

T. 5. (1992) Janusz Anusiewicz, Franciszek Nieckula (red.) Potoczność w języku i w kulturze;

T. 6. (1992) Janusz Anusiewicz i Małgorzata Marcjanik (red.) Polska etykieta językowa;

T. 7. (1992) Jolanta Maćkiewicz, Janusz Siatkowski (red.) Kontakty języka polskiego z innymi językami na tle kontaktów kulturowych;

T. 8. (1992) Iwona Nowakowska-Kempna (red.) Podstawy metodologiczne semantyki współczesnej;

T. 9. (1994) Janusz Anusiewicz, Kwiryna Handke (red.) Płeć w języku i kulturze;

T. 10. (1992) Janusz Anusiewicz, Bogdan Siciński (red.) Języki subkultur;

T. 11. (1994) Janusz Anusiewicz, Bogdan Siciński (red.) Język polityki a współczesna kultura polityczna;

T. 12. (1998) Janusz Anusiewicz, Jerzy Bartmiński (red.) Stereotyp jako przedmiot lingwistyki. Teoria, metodologia, analizy empiryczne;

T. 13. (2000) Anna Dąbrowska, Janusz Anusiewicz (red.) Językowy obraz świat i kultura. Itd.

JKW (2003) - Jerzy Bartmiński (red.) Język w kręgu wartości. Lublin: Wydawnictwo UMCS.

JWP (2006) - Jerzy Bartmiński (red.) Język, wartości, polityka. Zmiany rozumienia nazw wartości w okresie transformacji ustrojowej w Polsce. Raport z badań empirycznych. Lublin: Wydawnictwo UMCS.

Казлоўская-Дода, Ядвіга [Kazlouskaya-Doda, Yadviha] (2015) Панящие „дом” у сучаснай беларускай мове. Lublin: Wydawnictwo UMCS. 
Krzeszowski, Tomasz (1994) „Parametr aksjologiczny w przedpojęciowych schematach wyobrażeniowych”.

[W:] Jerzy Bartmiński (red.) Etnolingwistyka, t. 6. Lublin: Wydawnictwo UMCS; 29-51.

Krzyżanowski, Piotr, Paweł, Nowak (red.) (2004) Manipulacja w języku. Lublin: Wydawnictwo UMCS.

LASiS 1 (2015) - Jerzy Bartmiński, Iwona Bielińska-Gardziel, Beata Żywicka (red.) Leksykon aksjologiczny

Stowian i ich sasiadów, t. 1, DOM. Lublin: Wydawnictwo UMCS.

LASiS 3 (2016) - Jerzy Bartmiński, Małgorzata Brzozowska, Stanisława Niebrzegowska-Bartmińska (red.)

Leksykon aksjologiczny Stowian i ich sqsiadów, t. 3. PRACA. Lublin: Wydawnictwo UMCS.

LASiS 5 (2017) - Sotirov, Petar, Dejan, Ajdačić (red.) Leksykon aksjologiczny Slowian i ich sasiadów, t. 5, HONOR. Lublin: Wydawnictwo UMCS.

Lewicki, Andrzej, Maria (1984) [Rec.] Stownik ludowych stereotypów językowych. Zeszyt próbny. Wrocław 1980.

[W:] Mieczysław Szymczak (red.) Poradnik Językowy, nr 9-10. Warszawa - Łódź: PWN; 587-592.

Lewicki, Andrzej, Maria (red.) (1982) Stałość i zmienność związków frazeologicznych. Lublin: Wydawnictwo UMCS.

Lewicki, Andrzej, Maria, Ryszard, Tokarski (red.) (1995) Kreowanie świata w tekstach. Lublin: Wydawnictwo UMCS.

Левицкий, Андрей, Сергей, Потапенко, Ольга, Воробьева [Levickij, Andrej, Sergej, Potapenko, Olga,

Vorob'eva] (red.) (2013) Лингвоконцептология: перспективные направления. Монография. Луганск:

Изд-во ГУ „ЛНУ имени Тараса Шевченко”.

Ligara, Bronisława (2008) „Leksykultura w ujęciu Roberta Glissona a nauczanie kompetencji kulturowej”. [W:]

Władysław Miodunka, Anna Seretny (red.) W poszukiwaniu nowych rozwiazań. Dydaktyka języka polskiego

jako obcego u progu XXI wieku. Kraków: Wydawnictwo Uniwersytetu Jagiellońskiego; 51-60.

Łozowski, Przemysław (2014) „Język a kultura w programie etnolingwistyki kognitywnej Jerzego Bartmińskiego.

Między Sapirem a Malinowskim". [W:] Jerzy Bartmiński (red.) Etnolingwistyka, t. 26. Lublin: Wydawnictwo UMCS; 155-176.

Maksymiuk-Pacek, Beata, Stanisława, Niebrzegowska-Bartmińska (red.) (2009) Bibliografia adnotowana lubelskiego zespolu etnolingwistycznego (do roku 2009). Lublin: Polihymnia.

Marcjanik, Małgorzata (1993) „Etykieta językowa”. [W:] Jerzy Bartmiński (red.) Encyklopedia kultury polskiej

XX wieku. Wspótczesny język polski. Wrocław: Wiedza o kulturze; 270-281.

Marczewska, Marzena (2002) Drzewa w języku i w kulturze. Kielce: Wydawnictwo Akademii Świętokrzyskiej.

Miodunka, Władysław (red.) (2004) Kultura w nauczaniu języka polskiego jako obcego. Kraków: Universitas.

Nagórko, Alicja, Marek, Łaziński, Hanna, Burkhardt (2004) Dystynktywny stownik synonimów. Kraków: Universitas.

Nepop-Ajdaczyć Lidia (2007) Polska etnolingwistyka kognitywna. Kijów: CWP Uniwersytet Kijowski.

Nowak, Paweł, Ryszard, Tokarski (2007) Kreowanie światów w języku mediów. Lublin: Wydawnictwo UMCS.

Nowosad-Bakalarczyk, Marta (2009) Płeć a rodzaj gramatyczny we wspótczesnej polszczyźnie. Lublin: Wydawnictwo UMCS.

Mussolf, Andreas (2017) „Analiza scenariuszy metaforycznych w ramach lingwistyki kulturowej”. [W:] Waldemar Czachur (red.) Lingwistyka kulturowa $i$ międzykulturowa. Warszawa: Wydawnictwo Uniwersytetu Warszawskiego; 69-99.

Niebrzegowska, Stanisława (1995) Polski sennik ludowy. Lublin: Wydawnictwo UMCS. 
Niebrzegowska, Stanisława (1996) „Świat wartości sennika ludowego”. [W:] Jerzy Bartmiński (red.) Etnolingwistyka, t. 8. Lublin: Wydawnictwo UMCS; 99-112.

Niebrzegowska-Bartmińska, Stanisława (2004a) „Pojęcie wzorca tekstu a modelująca funkcja motywu”. [W:] Maria Wojtak, Małgorzata Rzeszutko (red.) W kręgu wiernej mowy. Lublin: Wydawnictwo UMCS; 283299.

Niebrzegowska-Bartmińska, Stanisława (2004b) „Badania etnolingwistyczne w Lublinie”. [W:] Zofia Krążyńska, Zdzisław Zagórski (red.) Poznańskie Spotkania Językoznawcze, t. 13. Poznań: Wydawictwo Poznańskiego Towarzystwa Przyjaciół Nauk; 79-89.

Niebrzegowska-Bartmińska, Stanisława (2007) Wzorce tekstów ustnych w perspektywie etnolingwistycznej. Lublin: Wydawnictwo UMCS.

Niebrzegowska-Bartmińska, Stanisława (2009) „Lubelski zespół etnolingwistyczny - jego historia i program badawczy”. [W:] Beata Maksymiuk-Pacek, Stanisława Niebrzegowska-Bartmińska (red.) Bibliografia adnotowana lubelskiego zespolu etnolingwistycznego (do roku 2009). Lublin: Polihymnia; 7-19.

Niebrzegowska-Bartmińska, Stanisława (2013) „Projekt badawczy (ETNO)EUROJOS a program etnolingwistyki kognitywnej”. [W:] Jerzy Bartmiński (red.) Etnolingwistyka, t. 25; Lublin: Wydawnictwo UMCS; 267-281. Niebrzegowska-Bartmińska, Stanisława (2014) „Od separacyjnego do holistycznego opisu językowego obrazu świata. Na marginesie dyskusji nad kształtem artykułów w „Leksykonie aksjologicznym Słowian i ich sąsiadów"'. [W:] Iwona Bielińska-Gardziel, Stanisława Niebrzegowska-Bartmińska, Joanna Szadura (red.) Wartości w językowo-kulturowym obrazie świata Stowian i ich sasiadów, t. 3. Lublin: Wydawnictwo UMCS; 71-102.

Niebrzegowska-Bartmińska, Stanisława (2015) „O profilowaniu językowego obrazu świata”. [W:] Poradnik Językowy $\mathrm{nr}$ 1. Warszawa; 30-44.

Niebrzegowska-Bartmińska, Stanisława (2017) „Czy definicja kognitywna jest definicja otwartą?”. [W:] Dorota Filar, Piotr Krzyżanowski (red.) Barwy słów. Studia lingwistyczno-kulturowe. Lublin: Wydawnictwo UMCS; 549-571.

Niebrzegowska-Bartmińska, Stanisława, Marta, Nowosad-Bakalarczyk, Tomasz, Piekot (red.) (2015) Działania na tekście: przekład - redagowanie - ilustrowanie. Lublin: Wydawnictwo UMCS.

Niebrzegowska-Bartmińska, Stanisława, Marta, Nowosad-Bakalarczyk, Tomasz, Piekot (red.) (2015) Działania na tekśsie w edukacji szkolnej i uniwersyteckiej. Lublin: Wydawnictwo UMCS.

Niebrzegowska-Bartmińska, Stanisława, Joanna, Szadura, Mirosław, Szumiło przy udziale Janusza Kłapcia (2014) Historia mówiona w świetle nauk humanistycznych i spolecznych. Lublin: Wydawnictwo UMCS.

NWwJE (2017) - Iwona Bielińska-Gardziel, Małgorzata Brzozowska, Beata Żywicka (red.) Nazwy wartości w językach europejskich. Raport $z$ badań empirycznych. Przemyśl: Państwowa Wyższa Szkoła Wschodnioeuropejska.

Pajdzińska, Anna, Piotr, Krzyżanowski (red.) (1999) Przeszłość w językowym obrazie świata. Lublin: Wydawnictwo UMCS.

Pajdzińska, Anna, Ryszard, Tokarski (red.) (2010) Relatywizm w języku i kulturze. Lublin: Wydawnictwo UMCS. Pajdzińska, Anna, Ryszard, Tokarski (red.) (2001) Semantyka tekstu artystycznego. Lublin: Wydawnictwo UMCS.

Palmer, Gary (1996) Toward a Theory of Cultural Linguistics. Austin: University Texas Press. 
Peeters, Bert (2015) Language, culture and values: towards an ethnolinguistics based on abduction and salience.

[W:] Jerzy Bartmiński (red.) Etnolingwistyka, t. 27. Lublin: Wydawnictwo UMCS; 47-62.

PSWP (2001) Zgółkowa Halina (red.) Praktyczny stownik współczesnej polszczyzny. Poznań: Wydawnictwo Kurpisz.

Putnam, Hilary (red.) (1975) Mind, Language and Reality. Philosophical papers, vol.2. Cambridge: Cambridge University Press.

Puzynina, Jadwiga (1992) Język wartości. Warszawa: Wydawnictwo Naukowe PWN.

PWJK (2004) - Jerzy Bartmiński, Stanisława Niebrzegowska-Bartmińska, Ryszard Nycz (red.) Punkt widzenia w języku i w kulturze. Lublin: Wydawnictwo UMCS.

Руденко, Елена [Rudenko, Elena] (2014) Этнолингвистика без грании. Введение в лингвистическую антропологию. Минск: БГУ.

Толстой, Никита [Tolstoj, Nikita] (red.) (1995-2012) Славянские древности: Этнолингвистический словарь.

Москва: Международные отношения.

SSiSL (2017) Jerzy Bartmiński, Stanisława Niebrzegowska (red.) Stownik stereotypów i symboli ludowych, t. 1, Kosmos, cz. 1-4. Lublin 1996-2012, t. 2, Rośliny, cz. 1, Zboża. Lublin: Wydawnictwo UMCS.

Степанов, Юрий [Stepanov, Jurij] (1997) Константы. Словарь русской культуры. Опыт исследования.

Москва: Школа „Языки русской культуры”.

Szadura, Joanna (2017) Czas jako kategoria językowo-kulturowa w polszczyźnie. Lublin: Wydawnictwo UMCS. Tabakowska, Elżbieta (2004) Językoznawstwo kognitywne a poetyka przekładu. Kraków: Universitas.

Tokarski, Ryszard (1993) „Słownictwo jako interpretacja świata”. [W:] Jerzy Bartmiński (red.) Encyklopedia kultury polskiej XX wieku. Wspótczesny język polski. Wrocław: Wiedza o kulturze; 335-362.

Tolstaja, Svetlana (2006) „Постулаты московской этнолингвистики”. [W:] Jerzy Bartmiński (red.) Etnolingwistyka, t. 18. Lublin: Wydawnictwo UMCS; 7-27.

Толстая, Светлана [Tolstaja, Svetlana] (2008) „Труд и мука” [W:] Пространство слова. Лексическая семантика в общеславянской перпективе. Москва: Индрик; 114-120.

Толстая, Светлана [Tolstaja, Svetlana] (2013a) „Никита Ильич Толстой и его путь к этнолингвистике”. [W:] Светлана Толстая, Татьяна Агапкина (red.) Ethnolinguistica Slavica. К 90-летию академика Никить Ильича Толстого. Москва: Индрик; 10-25.

Толстая, Светлана [Tolstaja, Svetlana] (2013b) „Коды культуры и культурные концепты” [W:] Толстая, Светлана Толстой, Никита. Славянская этнолингвистика: вопросы теории. Москва: Институт славяноведения РАН; 109-113.

Tolstoj, Nikita (1992) „Język a kultura: niektóre zagadnienia słowiańskiej etnolingwistyki”. [W:] Jerzy Bartmiński (red.) Etnolingwistyka, t. 5. Lublin: Wydawnictwo UMCS; 15-25.

Topolińska, Zuzanna (2018) „Praca w języku polskim i macedońskim”. [W:] Arkadiusz Bagłajewski, Jerzy Bartmiński, Monika Łaszkiewicz, Stanisława Niebrzegowska-Bartmińska (red.) Praca ludzka w perspektywie interdyscyplinarnej. Lublin: Wydawnictwo UMCS; 325-350.

Underhill, James (2012) Ethnolinguistics. Cambridge: Cambridge University Press.

Underhill, James (2014) „Tłumacząc home i homeland. Od poetyki do polityki”. [“Translating home and homeland. From poetics to politics"] (tłum.) Adam Głaz [W:] Jerzy Bartmiński (red.) Etnolingwistyka, t. 26. Lublin: Wydawnictwo UMCS; 87-105. 
Воробьев, Владимир [Vorob’ev, Vasiliy] (2008) Лингвокультурология. Москва: РУДН.

Wierzbicka, Anna (1993) „Nazwy zwierząt”. [W:] Jerzy Bartmiński, Ryszard Tokarski (red.) $O$ definicjach $i$ definiowaniu. Lublin: Wydawnictwo UMCS; 251-267.

Wierzbicka, Anna ([1997] 2007) Stowa klucze. Różne języki - różne kultury. [Understanding Cultures through Their Key Words. English, Russian, Polish, German, and Japanese. Oxford: Oxford University Press] (tłum.) Izabela Duraj-Nowosielska. Warszawa: Wydawnictwo Uniwersytetu Warszawskiego.

WJOSS 1 (2013) Maciej Abramowicz, Jerzy Bartmiński, Iwona Bielińska-Gardziel (red.) Wartości w językowokulturowym obrazie świata Stowian i ich sasiadów: 1. Analizy semantyczne domu, pracy, ojczyzny, wolności $i$ in. Lublin: Wydawnictwo UMCS.

WJOSS 2 (2014) Jerzy Bartmiński, Iwona Bielińska-Gardziel, Stanisława Niebrzegowska-Bartmińska (red.) Wartości w językowo-kulturowym obrazie świata Stowian i ich sqasiadów: 2. Wokót europejskiej aksjosfery. Lublin: Wydawnictwo UMCS.

WJOSS 3 (2014) Iwona Bielińska-Gardziel, Stanisława Niebrzegowska-Bartmińska, Joanna Szadura (red.) Wartości w językowo-kulturowym obrazie świata Stowian i ich sąsiadów: 3. Problemy eksplikowania i profilowania pojęć. Lublin: Wydawnictwo UMCS.

WJOSS 4 (2018) Stanisława Niebrzegowska-Bartmińska, Joanna Szadura, Beata Żywicka (red.) Wartości w językowo-kulturowym obrazie świata Stowian i ich sąsiadów: 4. Stownikjęzykowy-leksykon-encyklopedia w programie badań porównawczych, t. 4. Lublin: Wydawnictwo UMCS.

WJP (1993) Jerzy Bartmiński (red.) Encyklopedia kultury polskiej XX wieku. Współczesny język polski. Wrocław: Wiedza o kulturze.

Зализняк, Анна, Ирина, Левонтина, Алексей, Шмелев [Zaliznjak, Anna, Irina, Levontina, Aleksej, Šmelev] (2005) Ключевые идеи русской картины мира. Москва: Языки славянской культуры.

Zarzycka, Grażyna (2004) „Mały leksykon kultury polskiej dla cudzoziemców”. [W:] Władysław Miodunka (red.) Kultura w nauczaniu języka polskiego jako obcego. Kraków: Universitas; 151-160.

Zgółka, Tadeusz (2006) „Etnolingwistyka praktyczna”. [W:] Jerzy Bartmiński (red.) Etnolingwistyka, t. 18. Lublin: Wydawnictwo UMCS; 129-134.

Zinken, Jörg (2004) „Metaphors, stereotypes, and the linguistic picture of the world: Impulses from the Etnolinguistic School of Lublin”. [W:] Metaphorik.De, nr 7; 115-136.

Zinken, Jörg (2009) „The Ethnolinguistic School of Lublin and Anglo-American Cognitive Linguistics”. [W:] Bartmiński Jerzy, Aspects of Cognitive Ethnolinguistics. London \& Oakville: Equinox Publishing; 1-5.

Żmigrodzki, Piotr (2010) „Definicja leksykograficzna a opis języka - ćwierć wieku później. Jeszcze o roli naiwnego obrazu świata w definiowaniu". [W:] Wojciech Chlebda (red.) Etnolingwistyka a leksykografia. Opole: Wydawnictwo Uniwersytetu Opolskiego; 33-40.

Żuk, Grzegorz (2010) Twierdza czy wspólnota? Europa w polskim dyskursie publicznym. Lublin: Wydawnictwo UMCS.

Żywicka, Beata (2007) Miejsca i wartości. Zmiany w językowym obrazie przestrzeni we współczesnej polszczyźnie. Lublin: Polihymnia. 